\title{
Analysis of Optimum Garbage Heaps Age on Recovery of Landfills Dominated by Organic Solid Waste
}

\author{
Zaulfikar Abbas ${ }^{1,2^{*}}$, Sudarno Utomo ${ }^{1,3}$ and Budiyono ${ }^{1,4}$ \\ 1 Doctoral Program Environmental Sciences of Diponegoro University, Semarang 50241, Indonesia \\ 2 Industrial Engineering Department of Teuku Umar University, Meulaboh 23681, Indonesia \\ 3 Environmental Engineering Department of Diponegoro University, Semarang 50275, Indonesia \\ ${ }^{4}$ Chemical Engineering Department of Diponegoro University, Semarang 50275, Indonesia \\ * Corresponding author's e-mail: zaulfikar.abbas@utu.ac.id
}

\begin{abstract}
Landfills in developing countries, like Indonesia are dominated by organic solid waste, with water content reaching $80 \%$. It is impossible to manage them by incineration processes. Naturally, all organic material can decompose and produce methane gas, carbon, water, as well as leave blackish fine soil-like material, called compost. Therefore, the recovery of the landfills can be done by using landfill mining methods. However, the benefits, costs, and environmental impacts of landfill mining are highly dependent on landfills age, material characteristics, disposal systems, economic and social development of the community, and climate. The main objective of this study was to analyze the optimum age of garbage heaps to obtain the right time on the recovery of the landfills. Five excavation points were prepared at 4-5, 6-7, 8-9, 10-11, and $>12$ years. Each excavated material was dried, separated, and grouped according to each component, and then weighed, tabulated, and shown as a percentage of excavated garbage composition. The result shows that landfill mining can be carried out at a garbage heap aged 8-9 years in which compost landfill mining has obtained at 50\%. Other discussions concern the existence of organic and nonorganic components as well as the usage of plastic bags and nappies indicating the lifestyle changes of the people.
\end{abstract}

Keywords: organic solid waste, landfill, landfill mining, compost landfill mining

\section{INTRODUCTION}

Generally, landfills in developing countries, such as Indonesia, still use an open dumping system with bad management and poor processing facilities. The problem has become more complicated due to the high rate of urbanization, which directly affects the waste generated. The technical aspects, quality of human resources and financing are some of the main obstacles in implementing sanitary landfills (Scheinberg, 2010; Coordinating Ministry for Economic Affairs, 2013).

Many cities in developing countries, like in Indonesia are growing very fast, requiring the expansion of their area. The landfills that were previously far from the city centers and residential areas have become part of city centers and densely populated. Most areas around landfills have become urban slums and this constitutes a serious problem in Indonesia. The availability of a strategic urban land is also increasingly difficult to obtain.

On the other hand, landfills are sources of groundwater pollution and emissions of methane gas, carbon, and other hazardous substances in the long term (Mor et al., 2006; Sormunen et al., 2008). The condition becomes worse due to inadequate processes of sorting and transforming materials which can still be recycled and reused; this shortens their service life and requires the creation of new landfills. However, the land-based system is very vulnerable to community protests and is not easy to handle (Hadi, 2001; Chang and Davila, 2007).

Landfill mining is the right way to recover landfills. It will increase the economic value of 
the lands around the landfills. The cost of landfill mining is very high; however, the municipal government has a more important mission, which is avoiding burden costs after the closure of the landfills, adding strategic urban land and increasing land values after recovery of the landfill (Zee et al., 2004; Passel et al., 2013).

Landfill mining can also extend service life, rehabilitate, and recover landfills in which it also avert the environmental effects from leachate pollution or landfill gas emissions (Krook et al., 2012; Frändegård et al., 2013; Fisher and Findlay, 1995). Therefore, landfill mining can be adopted as a feasible way for the ecological recovery of ex-landfill (Krook, 2010; Krook and Baas, 2013).

However, the benefits, costs and environmental impacts of landfill mining are highly dependent on several factors, such as land age, material characteristics, depth of landfill waste, level of waste decomposition, hazardous material contents, disposal systems, economic/social development of local community, climate, humidity, and landfill location (Hogland, 2002; Zee et al., 2004; Krook et al., 2012; Rosendal, 2015).

Therefore, landfill mining in developed countries is different from that in developing countries. In Indonesia, landfills are dominated by organic solid waste, which reaches $70 \%$ and categorized as wet solid waste with water content up to $80 \%$ (Fehr, 2006).

Thus, management of solid waste by the combustion process is impossible. However, naturally, all organic material can decompose and produce methane gas, carbon, and water. The remaining organic material forms blackish fine soil-like material which is called compost.

There are many studies of landfill mining, but there are no specific studies regarding the age of the garbage heaps in order to obtain the right time on recovery of landfills, especially in an active landfill. The REMO Belgian landfill is one of the many old landfills. A study conducted in the landfill was reported, in which 4 locations for excavated samples were selected at 14, 19, 24 and 29 years (Quaghebeur et al., 2013). A similar study was carried out in Tamangapa landfill in Makassar Indonesia but at 6 years cells (Darwati, 2009).

The studies on the utilization of compost landfill mining as bio-cover were also been reported (Barlaz et al., 2004; Kurniasari et al., 2014; Silas et al., 2014). The majority of other studies are reviews of the potentials of landfill mining/ enhanced landfill mining, including mining metal materials (ferrous/non-ferrous) in ash heaps of incinerators (Quaghebeur et al., 2013; Jones et al., 2013; Frändegård et al., 2013; Beaven et al., 2014; Frändegård et al., 2015; Danthurebandara et al., 2015; Massarutto, 2015; Wagner and Raymond, 2015; Tanigaki et al., 2015; Burlakovs et al., 2016).

Since no studies about the right age of the garbage heaps, and also the characteristics of landfills in growing cities Indonesia which are different from other landfill are available, the main objective of this study was to obtain an optimum age of garbage heaps in producing compost landfill mining that can be used as the right time on the recovery of landfills in developing countries, especially in Indonesia, in which the landfills are dominated by organic solid waste with high water content. Other goals were to discuss the time effect on an increase in the percentage of compost landfill mining and provide an overview of the current condition of Banda Aceh people.

\section{METHODOLOGY}

This study was carried out in the Gampong Jawa Landfill, Banda Aceh, Sumatera - Indonesia. It was conducted from September to December 2018, starting with field observations to obtain the information on field conditions and the location of garbage heaps based on time.

The excavation was based on the age group of garbage heaps 4-5 years, 6-7 years, 8-9 years, $10-11$ years, and $\geq 12$ years. In each age group, the excavation was carried out at three different depths 3-4 meters, 6-7 meters and $\geq 9$ meters, then the percentage of the excavated garbage of each age group is an average of the three different depths. A long arm excavator was used due to temporary transfer and return of garbage over a large area.

The excavated garbage was dried under sunlight for 5-7 days, or until the weight stayed constant for the last three days. Then it was sorted manually by hand to separate rough materials including wood, plastic, metal, glass, rubbers, cloths, paper, cardboard, and other materials that do not have any economic or caloric values. The remaining material is called the compost landfill mining component, and together with rough materials it was weighed, tabulated, and determined as the composition of the excavated garbage. 


\section{RESULTS AND DISCUSSION}

\section{The percentage of compost landfill mining based on the age of garbage heaps}

The main objective of this study was to find out the amount of compost landfill mining that can be obtained based on the age of garbage heaps. This finding can be used as a wise consideration to recover a landfill at the right time. Table 1 shows the percentage of compost landfill mining and other rough materials.

Table 1 shows that the percentage of compost landfill mining increases along with the age of garbage heaps, respectively achieves $33.56 \%$ for 4-5 years, $38.46 \%$ for $6-7$ years, $50.31 \%$ for $8-9$ years, $63.82 \%$ for $10-11$ years and $55.91 \%$ for $\geq$ 12 years. In the age group of 10-11 years, there is a fairly high increase in compost landfill mining. In the same age group, the component of stone was obtained at $21.54 \%$. It is greater than of the other four groups, which vary from $5-11 \%$. The observation shows that the soil cover in the excavated point contains more rocks. Covering the garbage properly requires more soil and the soil was mixed as fine material. That is what causes the deviation of the amount of compost landfill mining obtained in the excavated point of 10-11 years.

The impact of the deviation gives a linear line equation (Figure 1):

$$
y=7.006 x+27.394
$$

If the linear line equation (1) is interpolated to the excavation point at $10-11$ years $(x=4)$, the estimated amount of compost landfill mining will be corrected in a large decrease from $63.82 \%$ to $55.42 \%$. At the excavation point $\geq 12$ years $(x=5)$ it will also be corrected from $55.91 \%$ to $62.42 \%$. If all data above is used, there are two pieces of inaccurate data, i.e. the data on excavation point at $10-11$ years and $\geq 12$ years. However, if the data on the excavation point at $10-11$ years is ignored, it gives a new linear regression equation (Figure 2). It will be corrected on the excavated point at $10-11$ years $(x=4)$ to $51.82 \%$. Then, on the excavation point $\geq$ at 12 years $(x=5)$ it will be corrected slightly from $55.91 \%$ to $57.62 \%$.

This correction shows that the percentage of compost landfill mining at the 10-11 year excavation point is slightly increased than the $8-9$ year excavation point in Table 1, i.e. $1.51 \%$. The increase is very small and does not have a significant impact. Therefore, the excavation data at excavation points of $10-11$ years and $\geq 12$ years can be ignored, and landfill mining activities can be carried out at the age of garbage heaps of 8-9 years.

Table 1 also shows that the $8-9$ year of garbage heap produced compost landfill mining exceeding $50 \%$. The increase of the age of the garbage heap in the next few years does not give a significant increase in the percentage of compost landfill mining. It shows that under the optimum conditions, the composting process can only reduce the volume of solid waste by $50-70 \%$ (Hadisumarno, 1992).

In Tamangapa Makasar landfill Indonesia, landfill mining was carried out at 6 year cells. The separation of fine material from plastic, paper, wood, stone, glass, metal, and others was done by using a mechanical trommel machine, producing $50-60 \%$ fine material measuring $<50 \mathrm{~mm}$ (Darwati, 2009). The percentage of fine material is slightly higher than this study because a lot of the

Table 1. The percentage of excavated garbage based on their age groups

\begin{tabular}{|c|l|c|c|c|c|c|}
\hline No. Components & \multicolumn{1}{|c|}{$\begin{array}{c}4-5 \text { years } \\
\%\end{array}$} & $\begin{array}{c}6-7 \text { years } \\
\%\end{array}$ & $\begin{array}{c}\text { 8-9 years } \\
\%\end{array}$ & $\begin{array}{c}10-11 \text { years } \\
\%\end{array}$ & $\begin{array}{c}\geq 12 \text { years } \\
\%\end{array}$ \\
\hline 1 & Compost landfill mining & 33.56 & 38.46 & 50.31 & 63.82 \\
\hline 2 & Plastic & 23.78 & 20.40 & 14.35 & 5.16 \\
\hline 3 & Metal & 1.64 & 2.77 & 0.65 & 0.34 \\
\hline 4 & Paper & 0.36 & 0.51 & 0.46 & 0.25 \\
\hline 5 & Wood & 6.17 & 4.44 & 2.83 & 2.04 \\
\hline 6 & Stone & 5.65 & 7.36 & 10.10 & 21.54 \\
\hline 7 & Coconut fibre & 9.86 & 7.23 & 7.91 & 2.31 \\
\hline 8 & Nappies & 14.01 & 9.99 & 8.03 & 11.77 \\
\hline 9 & Glass & 2.36 & 4.32 & 2.74 & 1.73 \\
\hline 10 & Cloth & 1.83 & 2.50 & 1.12 & 1.89 \\
\hline 11 & Rubber & 0.78 & 2.02 & 1.50 & 0.43 \\
\hline
\end{tabular}




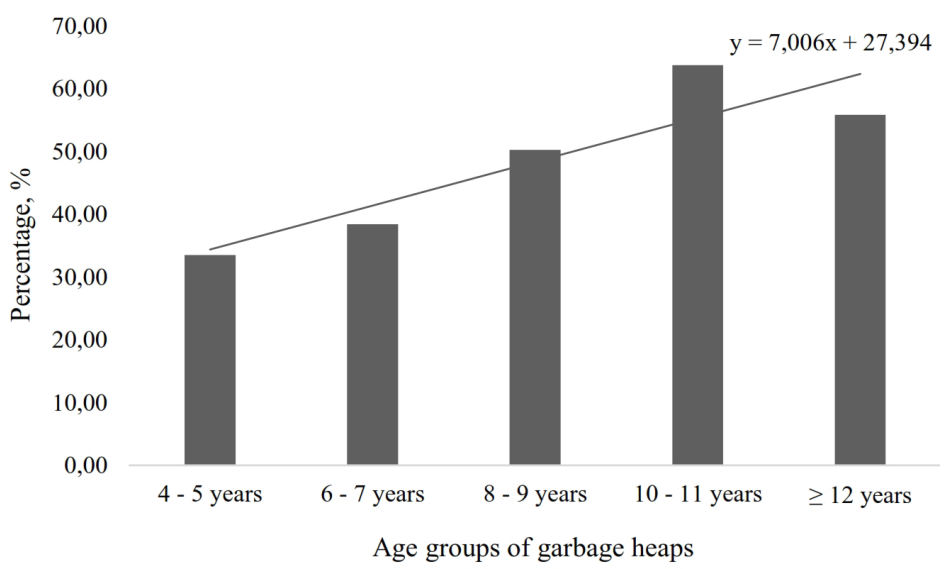

Figure 1. Percentage of compost landfill mining generated by age group

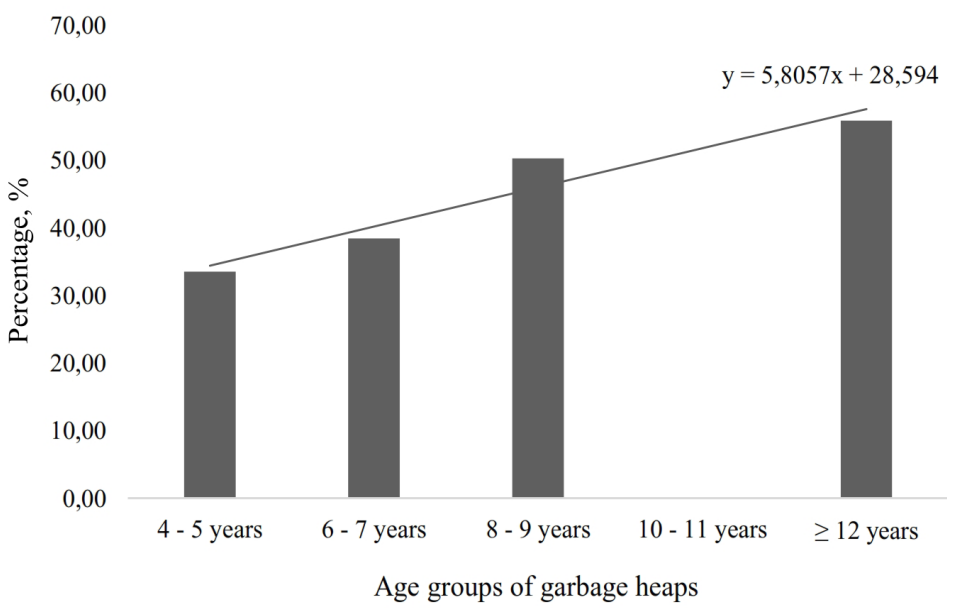

Figure 2. Percentage of compost landfill mining generated without the age group of 10-11 years

fraction of rocks passed the sifting machine. In this study, the separation of fine material, including small rocks, was obtained manually by hands (Figure 3).

A method for sifting the dry excavated material to separate fine and coarse material was also employed in the REMO Belgian landfill. The excavated samples were selected in 4 locations that varied at 14, 19, 24 and 29 years. Figure 4 shows the percentage of fine material obtained (40-50\%) (Quaghebeur et al., 2013).

\section{Time effect on an increase in the percentage of compost landfill mining}

Table 1 presents some non-organic components that show a small change of percentage, except plastic and stone. For example, the percentage of metals in 4-5 years is $1.64 \%$ and then it increases slightly to $2.77 \%$ in $6-7$ years. In $8-9$ years and $10 \mathrm{v} 11$ years the percentage of the metal component is small, $0.65 \%$ and $0.34 \%$ respectively. In group $\geq 12$ years, the percentage of metal is similar to the first two groups, which was $2.33 \%$. A similar phenomenon is also shown in the glass, cloth, and rubber components, in which the percentage of the components is also almost the same, except for glass components in 6-7 years which is slightly higher. The phenomenon shows that the existence of metal, glass, cloth, and rubber from year to year tends to be fixed as they do not decompose like organic materials (Figure 5).

Paper is an organic component, but its occurrence in the landfill is also relatively fixed. The paper waste such as those from office, books, newspapers, magazines, and cardboard boxes goes to recycling industries due to its economic value. As paper waste was sorted in households, shops, and also by scavengers, only a small amount of paper component ends up in the landfill - this type of paper waste is from beverage packaging wrapping coated with plastic, inside and outside, making it difficult to degrade naturally. 


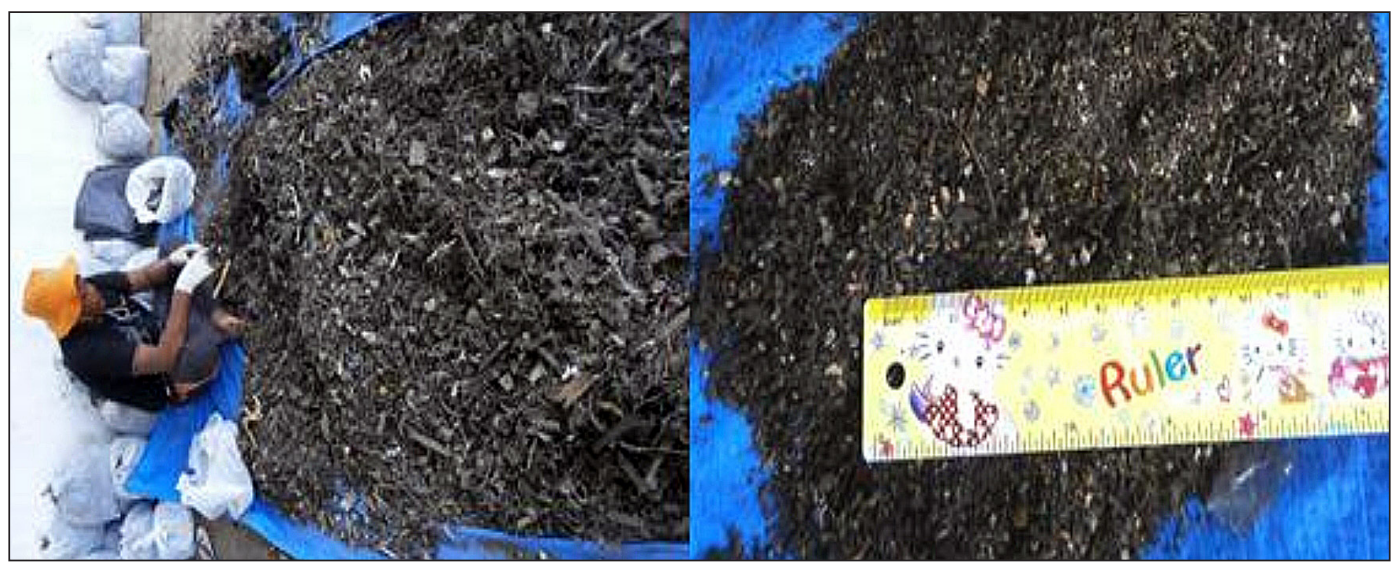

Figure 3. Manually sorted and size of fine material

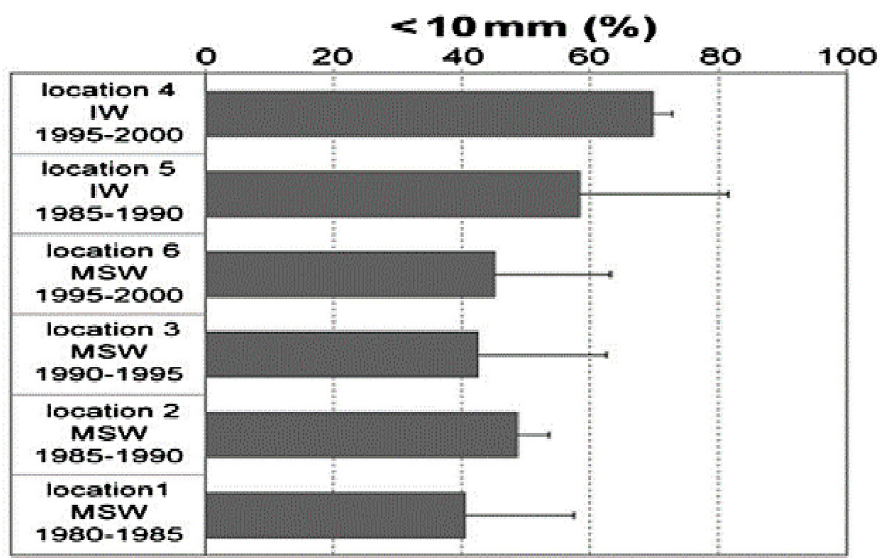

Figure 4. The percentage of fine materials at 14, 19, 24 and 29 years in REMO Landfill Belgium

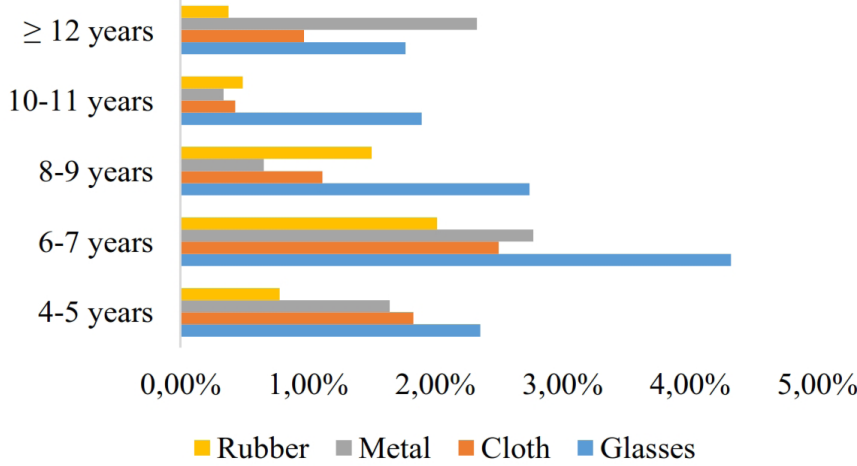

Figure 5. The percentage of non-organic components

The percentage changing of plastic components and nappies is very significant, and in a longer time, their percentage also decreases. However, this does not indicate that plastic and nappies have degraded through time. The phenomenon is related to a changing lifestyle of local people and this will be discussed in the next session.

Stone is a solid material, and its occurrence in the excavated garbage varied between $5.65-$ $11.77 \%$. It did not have a significant impact on the increase of compost landfill mining, except for that in the 10-11 years group which is $21.54 \%$ (as discussed above).

The two last components are wood and coconut fibre, which are classified as organic components. They can degrade through time and contribute to the increase of compost landfill mining percentage. In Table 1, the percentage of wood in the 6-7 years group is $4.44 \%$, assumed as a result of $1.73 \%$ further degradation from the $4-5$ years group. Meanwhile, the percentage of coconut fibre in the 6-7 years group is $7.23 \%$, assumed as 
a result of $2.63 \%$ further decomposition from the 4-5 years group. The sum of both extra decomposition percentages gives a value of $4.36 \%$, and if added to the percentage of compost landfill mining in the 4-5 years group, it will give a value of $37.92 \%$. This value is nearly similar to the percentage in the 6-7 years group, which is $38.46 \%$. This shows that the organic materials will decay over time naturally. However, further evidence in the next age groups did not provide a comparable value. It was assumed that the initial percentage of wood and coconut fibre components or other organic materials in other age groups are greater than the 4-5 years group and the organic materials have degraded naturally.

\section{The current condition of Banda Aceh people based on the solid waste generated}

Generally, the components of garbage heaps in this study are not much different from other landfills. However, there are interesting components to be discussed: plastic and nappies (including female sanitary pads). The components can indicate an aspect of the current condition of people of the Banda Aceh city that has been similar to a metropolitan community.

In Table 1, it can be seen that the percentage of plastic waste components obtained at the excavation point $\geq 12$ years is $14.22 \%$; this plastic waste was generated during the period of 2004-2005. However, the percentage of plastic components continues to increase over time. At the excavation point 6-7 years (2011-2012) the percentage reached $20.40 \%$. Furthermore, in the 4-5 year (2013-2014) it reached 23.78\%. The dominant plastic component is plastic bags. Plastic bag do not have sufficient economic value or heat value to be recycled, so it must end in a landfill site (Figure 6).
An increase in solid waste in the metropolitan community is also seen at the percentage of nappies component obtained, including female sanitary pads. At the excavation point $\geq 12$ years, that is around 2004-2005, the total percentage of nappies was only $2.37 \%$, but at the excavated point $8-9$ years and 4-5 years it increased sharply to $8.03 \%$ and $14.01 \%$. It shows that the income of the Banda Aceh people has been improving as they can afford these items. Unfortunately, it causes an increasing amount of plastic as a non-degradable waste that must also end in a landfill site.

On the basis of the discussion above, it can be concluded that the increase in the amount of solid waste is not solely caused by an increase in the human population. An increase in income, changes in lifestyle, and changes in consumption patterns also have a very serious impact on the solid waste generation. Therefore, even though people's perceptions and knowledge about waste are increasingly positive, it does not necessarily change the paradigm, mindset, and behavior of the community in minimizing solid waste significantly. A landfill is still the final solution to solid waste (Fehr, 2006; Mahyudin, 2017; Akhtar and Soetjipto, 2014).

\section{CONCLUSION}

The recovery of landfills dominated by organic solid waste with high water content, especially in developing countries, can be done by using landfill mining methods at the age of garbage heaps around 8-9 years. In the age, the percentage of compost landfill mining will be obtained in at least $50 \%$. The remaining excavated garbage can be sorted, separated and recycled ( $\geq 25 \%$ ), whereas the components which have no economic value

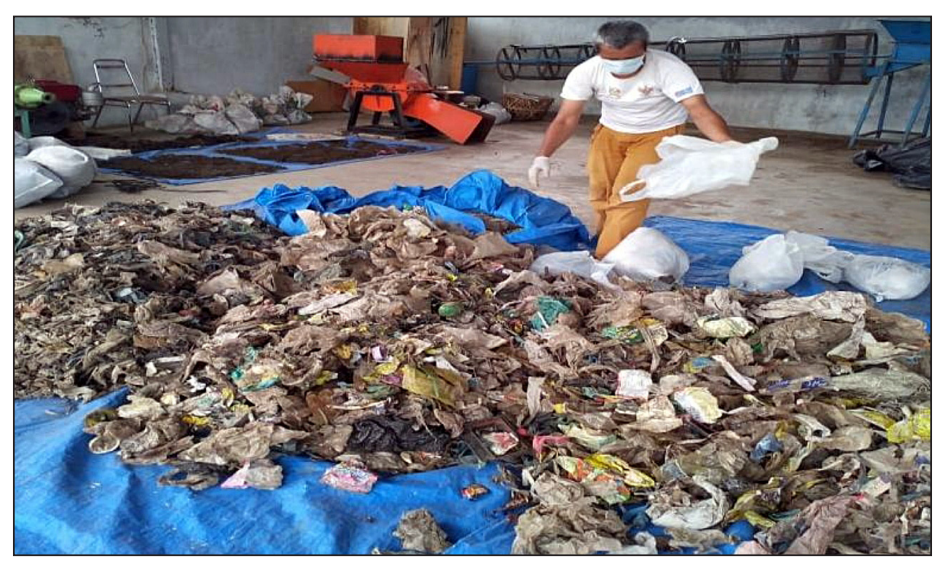

Figure 6. Plastic waste from excavated garbage 
and caloric value, i.e. plastic bags (14.35\%), nappies $(8.03 \%)$, and cloth $(1.12 \%)$, can be dumped in an active landfill $(\leq 25 \%)$.

The existence of metals, glasses, clothes, rubbers, and stones from year to year which tends to be permanent and not decomposed, shows that these materials are non-organic. Paper is an organic component, but its existence in the landfill is also relatively fixed. This is because paper has an economic value, so very few end up in landfills, except for beverage packaging in which the outer and inner layers are coated with plastic, making them difficult to degrade. Wood and coconut fibre are classified as organic materials and can be degraded, thus contributing to the increasing percentage of compost landfill mining.

Recently, the use of plastic bags and nappies by the Banda Aceh community has increased sharply. It shows that the income of the Banda Aceh people has been improving; the impact on the lifestyle-changing of the people consuming exclusive things, including disposable nappies and women sanitary pads. Unfortunately, it causes an increasing amount of plastic as a non-biodegradable waste that must also end in a landfill site. In turn, reusable nappies and sanitary pads which are environmentally friendly are becoming popular in developed countries, because people are more aware of the environment and the negative impacts of plastic waste.

\section{Acknowledgements}

The authors gratefully acknowledge the financial support of the Indonesia Endowment Fund for Education (FR 182018148706) and the technical support of the Ministry of Research, Technology and Higher Education of the Republic of Indonesia.

\section{REFERENCES}

1. Akhtar H., Soetjipto H.P. 2014. Peran Sikap Dalam Memediasi Pengaruh Pengetahuan Terhadap Perilaku Minimisasi Sampah Pada Masyarakat Terban, Yogyakarta (The Role of Attitude to Mediate The Effect of Knowledge on People's Waste Minimization Behaviour in Terban, Yogyakarta). Jurnal Manusia dan Lingkungan (Human And Environmental Journal), 21(3), 386-392.

2. Barlaz M.A., Green R.B., Chanton J.P., Goldsmith C.D., Hater G.R. 2004. Evaluation of a biologically active cover for mitigation of landfill gas emissions.
Environmental Science and Technology, 38(18), 4891-4899.

3. Beaven R.P., Knox K., Gronow J.R., Hjelmar O., Greedy D., Scharff H. 2014. A new economic instrument for financing accelerated landfill aftercare. Waste Management, 34(7), 1191-1198.

4. Burlakovs J., Kriipsalu M., Klavins M., Bhatnagar A., Vincevica-Gaile Z., Stenis J., Jani Y., Mykhaylenko V., Denafas G., Turkadze T., Hogland M., Rudovica V., Kaczala F., Rosendal R.M., Hogland W. 2016. Paradigms on landfill mining: From dump site scavenging to ecosystem services revitalization. Resources, Conservation and Recycling, 123, 73-84.

5. Chang N.-B., Davila E. 2007. Minimax regret optimization analysis for a regional solid waste management system. Waste Management, 27(6), 820-832.

6. Coordinating Ministry for Economic Affairs Republic of Indonesia 2013. Executive Summary: Studies on Sanitary Landfill Policy in Indonesia 2013, Jakarta Indonesia.

7. Danthurebandara M., Passel S. V, Vanderreydt I., Acker K. Van 2015. Assessment of environmental and economic feasibility of Enhanced Landfill Mining. Waste Management, 45, 434-447.

8. Darwati S. 2009. Potensi Rehabilitasi Tempat Pemerosesan Akhir Sampah Melalui Penambangan Lahan Urug (Potential Rehabilitation of landfill through Landfill Mining). Jurnal Pemukiman (Settlements Journal), 4(1), 29-37.

9. Fehr M. 2006. A successful pilot project of decentralized household waste management in Brazil. The Environmentalist, 26(1), 21-29.

10. Fisher H., Findlay D.M. 1995. Exploring the economics of mining landfills. Wolrd Wastes 38, 38(7), 11-15.

11. Frändegård P., Krook J., Svensson N. 2015. Integrating remediation and resource recovery: On the economic conditions of landfill mining. Waste Management, 42, 137-147.

12. Frändegård P., Krook J., Svensson N., Eklund M. 2013. A novel approach for environmental evaluation of landfill mining. Journal of Cleaner Production, 55, 24-34.

13. Hadi S.P. 2001. Dimensi Lingkungan Perencanaan Pembangunan (Dimensions of the Development Planning Environment), Yogyakarta - Indonesia: Gadjah Mada University Press.

14. Hadisumarno D. 1992. Buku Panduan Teknik Pembuatan Kompos dari Sampah: Teori dan Aplikasi (Handbook of Compost Making Techniques from Waste: Theory and Application), Jakarta Indonesia: Center for Policy and Implemantation Studies (CPIS).

15. Hogland W. 2002. Remediation of an old landsfill site: soil analysis, leachate qualityand gas production. Environmental Science and Pollution Research, 9(1), 49-54. 
16. Jones P.T., Geysen D., Tielemans Y., Passel S. V, Pontikes Y., Blanpain B., Quaghebeur M., Hoekstra N. 2013. Enhanced Landfill Mining in view of multiple resource recovery: A critical review. Journal of Cleaner Production, 55, 45-55.

17. Krook J. 2010. Urban and landfill mining: emerging global perspectives and approaches. Journal of Cleaner Production, 18, 1772-1773.

18. Krook J., Baas L. 2013. Getting serious about mining the technosphere: A review of recent landfill mining and urban mining research. Journal of Cleaner Production, 55, 1-9.

19. Krook J., Svensson N., Eklund M. 2012. Landfill mining: A critical review of two decades of research. Waste Management, 32(3), 513-520.

20. Kurniasari O., Damanhuri E., Padmi T., Kardena E. 2014. Tanah Penutup Landfill Mengunakan Sampah Lama Sebagai Media Oksidasi Metana Uuntuk Mengurangi Emisi Gas Metana (Soil cover landfill use old solid waste as methane oxidation media to reduce methane gas emissions). Jurnal Bumi Lestari (Journal of Sustainable Earth), 14(1), 46-52.

21. Mahyudin R.P. 2017. Kajian Permasalahan Pengelolaan Sampah dan Dampak Lingkungan di TPA(Study of waste problems and environmental impacts in landfill). Jukung Jurnal Tehnik Lingkugan (Jukung Environmental Engineering Journal), 3(1), 66-74.

22. Massarutto A. 2015. Economic aspects of thermal treatment of solid waste in a sustainable WM system. Waste Management, 37, 45-57.

23. Mor S., Ravindra K., Visscher A. De, Dahiya R.P., Chandra A. 2006. Municipal solid waste characterization and its assessment for potential methane generation: A case study. Science of the Total Environment, 371, 1-10.

24. Passel S. van, Dubois M., Eyckmans J., Gheldere S. de, Ang F., Jones P.T., Acker K. van 2013. The economics of enhanced landfill mining: Private and societal performance drivers. Journal of Cleaner Production, 55, 92-102.

25. Quaghebeur M., Laenen B., Geysen D., Nielsen P., Pontikes Y., Gerven T. V, Spooren J. 2013. Characterization of landfilled materials: Screening of the enhanced landfill mining potential. Journal of Cleaner Production, 55, 72-83.

26. Rosendal R. 2015. The economics of landfill mining shredder residue: focus on the aftercare. In: Conference: Proceedings Sardinia 2015, 15th International Waste Management and Landfill Symposium, At S. Margherita di Pula, Cagliari, Italy. Cagliari, Italia, pp. 5-9.

27. Scheinberg A. 2010. The Need for the Private Sector in a Zero Waste, 3-R, and Circular Economy Materials Management Strategy. Discussion paper for the CSD 18/19 Intercessional., Tokyo, Japan.

28. Silas J., Ratna S H., Setyawan W., Dewanti W., Hartatik, Firmaningtyas S. 2014. Revitalisasi Eks TPA Keputih Menjadi Taman Kota Untuk Mendukung Surabaya Menuju Eco-City (Revitalizing of the Keputih Landfill to be a city park to support Surabaya towards Eco-City). In: Simposium Nasional RAPI XIII-2014 FT UMS. UMS, pp. A1-A8.

29. Sormunen K., Ettala M., Rintala J. 2008. Detailed internal characterisation of two Finnish landfills by waste sampling. Waste Management, 28(1), 151-163.

30. Tanigaki N., Ishida Y., Osada M. 2015. A case-study of landfill minimization and material recovery via waste co-gasification in a new waste management scheme. Waste Management, 37, 137-146.

31. Wagner T.P., Raymond T. 2015. Landfill mining: Case study of a successful metals recovery project. Waste Management, 45, 448-457.

32. Zee D.J. van der, Achterkamp M.C., Visser B.J. de 2004. Assessing the market opportunities of landfill mining. Waste Management, 24(8), 795-804. 